\title{
TNF-A AND INTERLEUKIN 1-B INHIBITORY ACTIVITIES OF SOME SCORZONERA SPECIES
}

\author{
(C) Bahadır Acıkara O. ${ }^{1}$, Hošek J. ${ }^{2}$, Smejkal K. ${ }^{2}$, Çitoğlu G. S. ${ }^{1}$, Zemlicka M. ${ }^{2}$
}

${ }^{1}$ Ankara University, Faculty of Pharmacy, Department of Pharmacognosy, Turkey

${ }^{2}$ Department of Natural Drugs, Faculty of Pharmacy, University of Veterinary and Pharmaceutical Sciences Brno, Palackého 1-3, 61242 Brno, Czech Republic

Among the pro-inflammatory cytokines tumour necrosis factor- $\alpha$ (TNF- $\alpha$ ) and interleukin $1-\beta$ (IL-1 $\beta$ ) have a wide range of biological activities on numerous cell types and also reported to be involved in the pathogenesis of various inflammatory disorders (1-2). Scorzonera species (Asteraceae) are used to treat a variety of illnesses, including rheumatism, as well as for pain relief and wound healing in Turkish folk medicine (3-4). In current study some Scorzonera species; S. latifolia, S. cana var. jacquiniana, S.tomentosa, S. mollis ssp. szowitsii, S. eriophoa, S. incisa, S. cinerea and S. parviflora were evaluated for their anti-inflammatory activities by the inhibition of TNF- $\alpha$ and IL-1 $\beta$ production on LPS-stimulated THP-1 macrophages. All extracts showed anti-inflammatory activity. However among the tested extracts $S$. tomentosa aerial part has been established as the most active one. Additionally, S. latifolia aerial part extract displayed notable activity. Further studies are needed in order to clarify the bioactive principles responsible for these activities.

References: (1) Benbarek H, Deby-Dupont G, Deby C, Serteyn D. (2008). Direct stimulation of the oxidative activity of isolated equine neutrophils by TNF-alpha and IL-1beta. Veterinary Immunology and Immunopathology, 121: 101-106. (2) Rao PPN, Kabir SN, Mohamed T. (2010). Nonsteroidal Anti-Inflammatory Drugs (NSAIDs): Progress in Small Molecule Drug Development. Pharmaceuticals, 3: 1530-1549. (3) Sezik E, Yeşilada E, Tabata M, Honda G, Takaishi Y, Fujita T, Tanaka T, Takeda Y (1997) Traditional medicine in Turkey VIII. Folk medicine in East Anatolia; Erzurum, Erzincan, Ağr1, Kars, Iğdır Provinces. Econ Bot 51: 195-211. (4) Baytop T (1999) Türkiye'de Bitkiler ile Tedavi. Nobel Publishers, Ankara.

\section{PHYTOCHEMICAL ANALYSIS AND DEVELOPMENT TECHNOLOGY OF DRY EXTRACT OF COMMON BEANS}

\section{(C) Ozhigova M. G., Bobkova A. I., Pryachina N. I.}

\author{
St. Petersburg State Chemical and Pharmaceutical Academy, Russia
}

Bean pods (Phaseolus vulgaris L.) are among the most widely used traditional remedies against diabetes mellitus but it chemical composition is studied insufficiently. The purpose of this work was preliminary study of phytochemical composition of pods of common beans and development the technology of its extract. It was found that the pods of common beans contain flavonoids, polysaccharides, amino acids, saponins, organic acids, coumarins and sterines. According to literature antidiabetic activity of the common beans associated with the presence of flavonoids and polysaccharides. The total polysaccharides was $11,2 \pm 0,2 \%$. Glucose, galactose, fructose, arabinose have been identified. The common beans contains flavonoids such as quercetin and kaempferol derivatives.
Flavonoid content was determined by spectrophotometry and was $0,30 \pm 0,05 \%$ in rutin equivalents. Analysis of amino acids composition by paper chromatography showed the presence of arginine, asparagine, triptofan, leycine, lysine, methionine, and tyrosine. Bismaceration with heating was used to obtain the dry extract. At the first stage $70 \%$ ethyl alcohol was used as extragent and a ratio raw materials: extragent was 1:10. The yield of flavonoids was $72 \%$. In the second stage water was used as extragent and a ratio raw materials: extragent was $1: 10$. The yield of polysaccharides made $94 \%$. The phytochemical analysis of common beans was carried out. The technology of dry extract containing the sum of polysaccharides and flavonoids from bean pods was developed. 